doi: 10.5862/MCE.68.9

\title{
The elementary mathematical model of sustainable enclosing structure
}

\author{
Простая модель теплоустойчивой \\ ограждающей конструкции
}

\author{
E.A. Statsenko, \\ A.F. Ostrovaia, \\ T.A. Musorina, \\ M.I. Kukolev, \\ M.R. Petritchenko, \\ Peter the Great St. Petersburg Polytechnic \\ University, St. Petersburg, Russia
}

\author{
Студент Е.А. Стаценко, \\ студент А.Ф. Островая, \\ студент Т.А. Мусорина, \\ д-р. техн. наук, профессор М.И. Куколев, \\ д-p. техн. наук, заведующий кафедрой \\ М.Р. Петриченко, \\ Санкт-Петербургский политехнический \\ университет Петра Великого, г. Санкт- \\ Петербург, Россия
}

Key words: buildings; construction; civil engineering; energy efficiency; temperature; humidity conditions; the accumulation of heat; wall enclosure; problem of Cauchy
Ключевые слова: здания; строительство; гражданское строительство; энергоэффективность; температура; влажность; накопление тепла; ограждающие конструкции; задача Коши

\begin{abstract}
Energy efficiency building envelopes (walls, floors, facades) should meet the requirements of regulatory documents. The main attention is paid to structural and technological activities aimed at increasing the thermal resistance of protections. Estimates of the thermal stability of the wall are required for realization of high thermal resistance of the wall structure. The object of study is a simple model of the building envelope. It has been shown that the increased thermal conductivity, thermal resistance does not always provide the steady-state temperature faces the wall. Research method is based on the analysis of the properties of the Cauchy problem. In this article it is found out the connection between the active (thermal resistance) and reactive (accumulation) resistance enclosure on the model of one-dimensional wall.
\end{abstract}

Аннотация. Энергоэффективность ограждающих конструкций (стен, перекрытий, фрасадов) должна соответствовать требованиям нормативных документов. В настоящее время основное внимание уделяется конструктивно-технологическим мероприятиям, направленных на увеличение термического сопротивления ограждений. Реализация повышенного термического сопротивления стеновой конструкции требует оценок термической устойчивости стены. Объектом исследования является многослойная ограждающая конструкция. Показано, что повышенное термическое сопротивление теплопроводности не всегда обеспечивает стационарность температур граней стены. В работе описывается важность следующих фракторов: оптимизация температурновлажностного режима стен; влияние включений на величину потерь теплоты; влияние двойных фасадов на тепловые потери; эффективность применения новых теплоизоляционных материалов на термическое сопротивление и энергоэффективность. В данной статье выясняется связь между активным (термическое сопротивление) и реактивным (аккумуляция) сопротивлениями ограждения на модели одномерной стенки.

\section{Introduction}

Optimization of temperature and humidity of the walls [1], impact of inclusions on the magnitude of heat loss and thermal resistance of protections [2], the influence of the double facades on heat loss [3], the effectiveness of new insulating material, including membranes fire, for thermal resistance and energy efficiency [4], cetera are studied. But from the list of particular problems, as a rule, issues of thermal stability of fences and related issues determining the accumulation of heat protections are overlooked.

Statcenko E.A., Ostrovaia A.F., Musorina T.A., Kukolev M.I., Petritchenko M.R. The elementary mathematical model of sustainable enclosing structure. Magazine of Civil Engineering. 2016. No. 8. Pp. 86-91. doi: 10.5862/MCE.68.9 
The accumulation capacity enclosure determines the amount of heat which is essential to maintain the desired temperature level, and the walls enclosing the room when the temperature of the external source (sink) is rising. Construction is thermally stable if the rate of temperature changes at any point of the structure does not exceed a certain limiting value. Otherwise, if the temperature of the building envelope $\mathrm{T}=\mathrm{T}(\mathrm{t}, \mathrm{x})$, then $\max \left|\frac{\partial T}{\partial t}\right|_{x \in X}<c_{T}$; or, too, the speed of temperature change is uniformly bounded on $X$ values spatial coordinate $X$.

The article [1] considers thermal properties of different structural systems of ventilated facades. In [3], the authors explain the sufficient conditions necessary for the existence of free convective flow in a vertical slot channel.

Problem solutions of hydraulics non-isothermal free-convective flows of hinged ventilated facade are less represented. The number of articles on thermal transmission and hydrodynamics of ventilated air spaces of hinged ventilated facade is less then number of articles on optimization of the thermal resistance of wall fences.

The problem solution of energy saving in buildings is the subject of many studies. Calculation method of the coefficient of heat engineering design efficiency, taking into account the influence of structural elements, is proposed [5-6].

At present, the issue of the influence of the building envelope thermal protection level on the amount of thermal energy losses in the building, which is considered in the article [7].

The purpose of the article is to clarify relation between the active and reactive resistances protections on the model of one-dimensional wall

For this purpose it is necessary to complete next tasks: wall;

1. Consider the three inequalities that express restrictions on the instantaneous temperature of the

2. To analyze the properties of the Cauchy problem.

\section{Methods}

In normalized coordinates the problem is posed as follows:

$$
\begin{gathered}
\frac{\partial u}{\partial t}=\frac{\partial}{\partial x}\left(a(x) \frac{\partial T}{\partial x}\right), t>0,0<x<1 \\
\left(\frac{\partial u}{\partial x}\right)_{x=0}+h_{0}\left(\theta_{0}(t)-u(t, 0)\right)=\left(\frac{\partial u}{\partial x}\right)_{x=1}+h_{1}\left(u(t, 1)-\theta_{1}(t)\right)=0, t>0, u(t, 0)=0 .
\end{gathered}
$$

where $\mathrm{u}(\mathrm{t}, \mathrm{x})$ - the wall temperature, $\mathrm{x}$ - coordinate (in fractions of a wall thickness $\delta$ ), $\mathrm{t}-\mathrm{the}$ dimensionless time (the number of Fourier $t:=\mathscr{F}=\frac{a_{0} \tau}{\delta^{2}} \tau-$ "physical" time), $\theta_{0,1}$ - temperature of source, hot and cold, respectively (given), $h_{0,1}$ - dimensionless thermal transmission from an external source to the wall with hot and cold side (Biot number, specified), $a=a(x)$ - reduced coefficient of thermal conductivity, $\quad a:=\frac{\lambda}{a_{0} \rho c}$, given. This structure of wall is shown in Figure. 1.

Стаценко Е.А., Островая А.Ф., Мусорина Т.А., Куколев М.И., Петриченко М.Р. Простая модель теплоустойчивой ограждающей конструкции // Инженерно-строительный журнал. 2016. № 8(68). С. 86-91. 


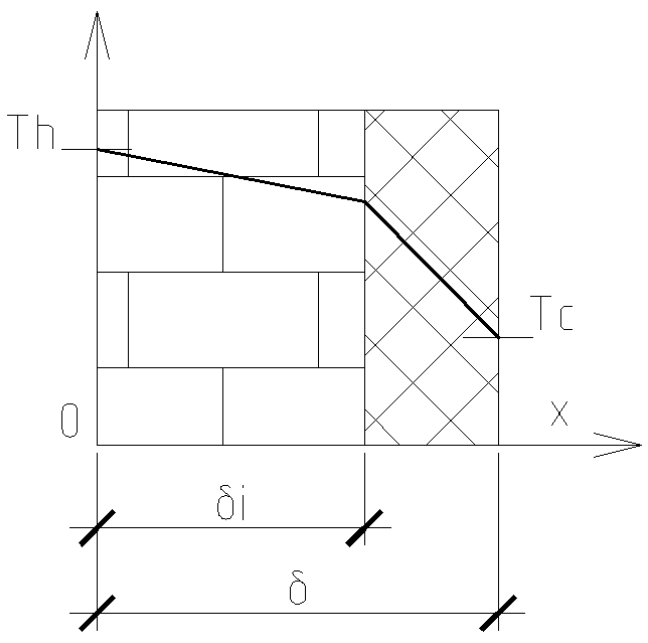

Figure. 1. The temperature distribution over the thickness of the wall

Boundary-value problem (1) is well known in the classical theory [8, 9]. Traditional methods of its solution badly work at temperatures of external sources and thermal transmission coefficients, changing in time [10-11].

It is important to note three inequalities expressing constraints on the instantaneous wall temperature:

$$
\theta_{1}(t) \leq u(t, 1)<u(t, 0) \leq \theta_{0}(t)
$$

and properties of the semicontinuity of limit wall temperatures as functions of Biot number. That is:

$$
\theta_{0}(t) \geq \limsup _{h_{0} \rightarrow \infty} u(t, 0), \theta_{1} \leq \liminf _{h_{1} \rightarrow \infty} u(t, 1) \text {. }
$$

In order to simulate the temperature distribution, $\mathrm{u}=\mathrm{u}(\mathrm{t}, \mathrm{x})$ the integral identity which is obtained from the equation of the boundary-value problem $(1)[8-9,12]$ is used:

$$
\begin{gathered}
\frac{d}{d t} \int_{0}^{1} u(t, x) d x=H_{0}\left(\theta_{0}-u(t, 0)\right)-H_{1}\left(u(t, 1)-\theta_{1}\right), \\
H_{0}:=a(0) h_{0}, H_{1}:=a(1) h_{1} .
\end{gathered}
$$

The left side of identity (2) is instantaneous speed of the average fence temperature change, that is measure of its thermal stability. On the right side of (2) the balance of the heat flux, "corrected" (authors multiply by coefficient of thermal conductivity in the limit points $x=0, x=1$ ) with account of the variability of the wall thermal properties along the heat flow $[13,14]$ is written.

Identity (2) can be converted to a differential equation for the limit temperature $u(t, 0):=\vartheta_{0}(t)$.

Let us assume that $u(t, x)=\vartheta_{0(t)} \exp (-m(t) x)$. Due to the expression (2) we get:

$$
\frac{d}{d t}\left(\frac{\vartheta_{0}}{m}\left(1-e^{-m}\right)\right)=H_{0}\left(\theta_{0}-\vartheta_{0}\right)-H_{1}\left(\vartheta_{0} e^{-m}-\theta_{1}\right)=0,
$$

where obviously $\vartheta_{0}(0)=0$.

If $m<<1$ we obtain the following Cauchy problem for the determination $\vartheta_{0}(\mathrm{t})$ :

$$
\frac{d \vartheta_{0}}{d t}+\left(H_{0}+H_{1}\right) \vartheta_{0}=H_{0} \theta_{0}+H_{1} \theta_{1}, \vartheta_{0}(0)=0
$$

Statcenko E.A., Ostrovaia A.F., Musorina T.A., Kukolev M.I., Petritchenko M.R. The elementary mathematical model of sustainable enclosing structure. Magazine of Civil Engineering. 2016. No. 8. Pp. 86-91. doi: 10.5862/MCE.68.9 
Knowing $\vartheta_{0}(t)$ and making use of identity $m=\frac{h_{0} \theta_{0}}{h_{0}+\vartheta_{0}}$, we can find the exponent $\mathrm{m}(\mathrm{t})$ for the next iteration. As seen in $h_{0}<<1$ assumption concerning the smallness of the $m(t)$ is correct. Conversely, if $h_{0}>>1$, then $m(t)=\theta_{0}(t)$. Then the temperature approximation has the form (3.1):

$$
u(t, x)=\vartheta_{0}(t) \exp \left(-x \theta_{0}(t)\right) .
$$

Then, $\vartheta_{1}(t)=\vartheta_{0} \exp \left(-\theta_{0}(t)\right)$, from which we immediately obtain that the $h_{0}>1$ temperature of hot source $\theta_{0}(t)$ is the logarithmic average of wall temperatures in limiting points: $\theta_{0}(t)=\ln \frac{\vartheta_{0}(t)}{\vartheta_{1}(t)}$.

Results are based on simple properties of the solution (4) of the Cauchy problem (3).

\section{Results and Discussion}

These properties are formulated as lemmas without evidence.

Lemma 1. The solution of the Cauchy problem (3) has the form:

$$
\vartheta_{0}(t)=\int_{0}^{t}\left(H_{0} \theta_{0}+H_{1} \theta_{1}\right)(\tau) \exp \left(-\int_{\tau}^{t}\left(H_{0}+H_{1}\right)(\omega) d \omega\right) d \tau
$$

$\tau, \omega-$ integration variables.

Lemma 2. Let $\mathrm{t} \rightarrow \infty$. Then:

$$
\lim _{t \rightarrow \infty} \vartheta_{0}(t)=\left(\frac{H_{0} \theta_{0}+H_{1} \theta_{1}}{H_{0}+H_{1}}\right)_{t=\infty}
$$

Otherwise, the limiting (conservative) value of the temperature of the "hot" wall face is equal to the weighted average (based on thermal transfer, "corrected" to the wall thermal diffusivity nonuniformity) temperature of the hot and cold sources.

Lemma 3. Let the "corrected" thermal transfer coefficients $\left(H_{i=0.1)}\right.$ and the temperature of the source $\left(\theta_{i=0.1)}\right.$ are constant. Then the solution (4) takes the form:

$$
\vartheta_{0}(t)=\frac{H_{0} \theta_{0}+H_{1} \theta_{1}}{H_{1}+H_{0}}\left(1-\exp \left(-\left(H_{0}+H_{1}\right) t\right)\right)
$$

Further:

$$
d \vartheta_{0} / d t=\left(H_{0} \theta_{0}+H_{1} \theta_{1}\right) \exp \left(-t\left(H_{0}+H_{1}\right)\right) \underset{t \rightarrow \infty}{\rightarrow}+0 .
$$

The article [15-17] revealed the fact that the regulatory requirements to the level of thermal protection were lower, even though slightly, than in the requirements of the standards in 2003 (Russian Set of Rules SP 23-02-2003). Consequently, the building meets the requirements of the current Set of rules, would not provide the necessary heat protection in the present circumstances. Moreover, many construction companies do not always comply with them.

Expression (5) is also valid for slowly varying distributions $\theta_{\mathrm{i}=0.1}$ (temperature of sources) $H_{\mathrm{i}=0.1}$ (thermal transfer coefficients).

If the temperature of the hot wall face changes linearly, then for any finite value $t>0$ of the cold source changes exponentially with time: $\theta_{1}(t) \approx \exp \left(t H_{1}\right)$. Otherwise, the rate of change of the temperature of the source and the wall faces is different: an exponential change of source temperature leads to a linear change in the wall face temperature.

In all cases, the wall storage capacity smoothes the temperature fluctuations on the wall surface. storage capacity (smoothing changes in temperature of sources - air) of the construction fence is the more, the more the value of the mentioned above thermal transfer coefficients $H_{i=0,1}$, that is, the more the thermal diffusivity coefficients $a_{i=0,1}$ of the wall faces. Thus, the implementation of the increased thermal resistance of walls through the use of heat-insulating materials with low thermal diffusivity comes into conflict with the thermal resistance of the fence. As it show in the article [18-20] thermal resistance of the ventilated facade is increased.

Стаценко Е.А., Островая А.Ф., Мусорина Т.А., Куколев М.И., Петриченко М.Р. Простая модель теплоустойчивой ограждающей конструкции // Инженерно-строительный журнал. 2016. № 8(68). С. 86-91. 


\section{Conclusions}

1. If $H_{0}=0$, hot wall face is insulated, the instantaneous speed of the hot wall temperature $\left(d \vartheta_{0}(t) / d t\right)$ is determined only by the "cold" source:

$$
d \vartheta_{0} / d t=H_{1} \theta_{1}(t) \exp \left(-t H_{1}\right)
$$

2. The maximum rate of temperature change does not exceed the set values for all $t H_{1} \exp \left(-t H_{1}\right)$ of the cold source temperature $\theta_{1}(t)$ :

$$
d^{2} \vartheta_{0} / d t^{2}=\left(\frac{d \theta_{1}}{d t} H_{1}-H_{1}^{2} \theta_{1}\right) \exp \left(-t H_{1}\right)
$$

3. When the final heat transfer on hot and cold faces, we have:

$$
d^{2} \vartheta_{0} / d t^{2}=\left(\frac{d \theta_{0}}{d t} H_{0}+\frac{d \theta_{1}}{d t} H_{1}-\left(H_{0}+H_{1}\right)\left(H_{0} \theta_{0}+H_{1} \theta_{1}\right)\right) \exp \left(-t\left(H_{0}+H_{1}\right)\right)
$$

4. So, when the linear (low) temperature changes reduced brink $\theta_{0} H_{0}+\theta_{1} H_{1}$ source temperature is proportional to $\exp \left(t\left(H_{0}+H_{1}\right)\right)$.

\section{References}

1. Tusnina O.A., Yemelyanov A.A., Tusnina V.M. Teplotekhnicheskiye svoystva razlichnykh konstruktivnykh sistem navesnykh ventiliruyemykh fasadov. [Thermal properties of different structural systems of ventilated facades]. Magazine of Civil Engineering. 2013. No. 8. Pp. 54-88. (rus)

2. Gorshkov A.S., Rymkevich P.P. Diagrammnyy metod opisaniya protsessa nestatsionarnoy teploperedachi. [Diagram description the method of non-stationary heat transfer process]. Magazine of Civil Engineering. 2015. No. 8(60). Pp. 68-82. (rus)

3. Petrichenko M., Vatin N., Nemova D., Olshevskiy V. The results of experimental determination of air output and velocity of flow in double skin facades. Applied Mechanics and Materials. 2015. No. 725-726. Pp. 93-99.

4. Zemitis J., Borodinecs A., Frolova M. Measurements of moisture production caused by various sources. Energy and Buildings. 2016. No. 127. Pp. 884-891.

5. Korniyenko S.V. Povysheniye teplozashchity stenovykh konstruktsiy zdaniy iz blokov. [Increase thermal protection wall structures of the building blocks of bulk]. Construction of Unique Buildings and Structures. 2016. No. 8(47). Pp. 17-30. (rus)

6. Kaklauskas A., Rute J, Zavadskas E., Daniunas A., Pruskus V., Bivainis J., Gudauskas R., Plakys V. Passive House model for quantitative and qualitative analyses and its intelligent system. Energy and Buildings. 2012. No. 50. Pp. 7-18.

7. Kornienko S.V., Vatin N.I., Petrichenko M.R., Gorshkov A.S. Evaluation humidity conditions multilayer wall structure in the annual cycle. Construction of Unique Buildings and Structures. 2015. No. 6. Pp. 19-33.

8. Kukolev M. I., Petrichenko M. R. Opredeleniye temperaturnogo polya stenki pri periodicheskom teplovom vozdeystvii. [Determination of the temperature field wall with periodic exposure to heat]. Dvigatel-2007, Trudy mezhdunarodnoy konferentsii. [Proceeding of international conference]. Moskva. MGTU. 2007. Pp. 115-119. (rus)

9. Zaborova D., Petrochenko M., Chernenkaya L. Thermal Stability Influence of the Enclosure Structure on the Building's Energy Efficiency. MATEC Web of Conferences. 2016. No. 53. Pp. $2-7$.

10. Ostrovaja A.F., Petrichenko M.R., Stacenko E.A. The glass ventilated facades. Research of an air gap. Applied Mechanics and Materials. 2015. Pp. 725-726. Pp. 87-92.

\section{Литература}

1. Туснина О.А., Емельянов А.А., Туснина В.М. Теплотехнические свойства различных конструктивных систем навесных вентилируемых фасадов // Инженерно-строительный журнал. 2013. № 8. С. 54-88.

2. Горшков А.С., Рымкевич П.П. Диаграммный метод описания нестационарной теплопроводности // Инженерно-строительный журнал. 2015. № 8. С. 68-82.

3. Petrichenko M., Vatin N., Nemova D., Olshevskiy V. The results of experimental determination of air output and velocity of flow in double skin facades // Applied Mechanics and Materials. 2015. № 725-726. Pp. 93-99.

4. Zemitis J., Borodinecs A., Frolova M. Measurements of moisture production caused by various sources // Energy and Buildings. 2016. № 127. Pp. 884-891.

5. Корниенко С.В. Повышение теплозащиты стеновых конструкций зданий из объемных блоков // Строительство уникальных зданий и сооружений. 2016. № 8(47). C. 17-30.

6. Kaklauskas A., Rute J, Zavadskas E., Daniunas A., Pruskus V., Bivainis J., Gudauskas R., Plakys V. Passive House model for quantitative and qualitative analyses and its intelligent system // Energy and Buildings. 2012. № 50. Pp. 7-18.

7. Kornienko S.V., Vatin N.I., Petrichenko M.R., Gorshkov A.S. Evaluation humidity conditions multilayer wall structure in the annual cycle // Construction of Unique Buildings and Structures. 2015. № 6. Pp. 19-33.

8. Куколев М.И., Петриченко М.Р. Определение температурного поля стенки при периодическом тепловом воздействии // Двигатель-2007. Сборник научных трудов по материалам Международной конфреренции. Москва. МГТУ. 2007. С. 115-119.

9. Zaborova D., Petrochenko M., Chernenkaya L. Thermal Stability Influence of the Enclosure Structure on the Building's Energy Efficiency. MATEC Web of Conferences. 2016. № 53. Pp. 2-7.

10. Ostrovaja A.F., Petrichenko M.R., Stacenko E.A. The glass ventilated facades. Research of an air gap // Applied Mechanics and Materials. 2015. Vol. 725-726. Pp. 87-92.

11. Vatin N., Petrichenko M., Nemova D. Hydraulic methods for calculation of system of rear ventilated facades // Applied Mechanics and Materials. 2014. Vols. 633-634. Pp. 10071012.

12. Vatin N.I., Gorshkov A.S., Nemova D.V., Staritcyna A. A., Tarasova D. S. The energy-efficient heat insulation

Statcenko E.A., Ostrovaia A.F., Musorina T.A., Kukolev M.I., Petritchenko M.R. The elementary mathematical model of sustainable enclosing structure. Magazine of Civil Engineering. 2016. No. 8. Pp. 86-91. doi: 10.5862/MCE.68.9 
11. Vatin N., Petrichenko M., Nemova D. Hydraulic methods for calculation of system of rear ventilated facades. Applied Mechanics and Materials. 2014. Vol. 633-634. Pp. 10071012.

12. Vatin N.I., Gorshkov A.S., Nemova D.V., Staritcyna A. A., Tarasova D. S. The energy-efficient heat insulation thickness for systems of hinged ventilated facades. Advanced Materials Research. 2014. Vol. 941-944. Pp. 905-920.

13. Petrichenko M.R., Petrochenko M.V., Yavtushenko Ye.B Gidravlicheski optimalnaya ventiliruyemaya shchel. [Hydraulically optimum vented slot]. Magazine of Civil Engineering. 2013. No. 2(37). Pp. 35-40. (rus)

14. Knat'ko M.V., Efimenko M.N., Gorshkov A.S. On the question of durability and energy efficiency of modern fencing wall construction of residential, administrative and industrial buildings. Magazine of Civil Engineering. 2008. No. 2. Pp. 50-53.

15. Olshevskyi V., Statsenko E., Musorina T., Nemova D., Ostrovaia A. Moisture transfer in ventilated facade structures. MATEC Web of Conferences. 2016. Vol. 53. Pp. 1-5.

16. Korniyenko S. Evaluation of thermal performance of residential building envelope. Procedia Engineering. 2015. Vol. 117. Pp. 191-196.

17. Gorshkov A.S., Rymkevich P.P., Vatin N.I. Simulation of non-stationary heat transfer processes in autoclaved aerated concrete-walls. Magazine of Civil Engineering. 2014. No. 8. Pp. 38-48.

18. Rosca A.V., Pop I. Flow and heat transfer over a vertical permeable stretching/shrinking sheet with a second order slip. International Journal of Heat and Mass Transfer. 2013. No. 60. Pp. 355-364.

19. Vatin N.I., Nemova D.V. Povyishenie energoeffektivnosti zdaniy detskih sadov [Improving the energy efficiency of buildings kindergartens]. Construction of Unique Buildings and Structures. 2012. No. 3. Pp. 52-76. (rus)

20. Musorina T., Olshevskyi V., Ostrovaia A., Statsenko E. Experimental assessment of moisture transfer in the vertical ventilated channel. MATEC Web of Conferences. TPACEE 2016. 2016. Vol. 73. No. 02002.

\section{Elena Statcenko,}

+7(981)8398538; staclena@mail.ru

Anastasia Ostrovaia,

+7(953)3449063; stasya2609@yandex.ru

Tatyana Musorina,

+7(952)2860376; flamingo-93@mail.ru

Maksim Kukolev,

+7(921)7540087; m_kukolev@mail.ru

Mikhail Petritchenko,

+7(921)3300429; fonpetrich@mail.ru thickness for systems of hinged ventilated facades // Advanced Materials Research. 2014. Vols. 941-944. Pр. 905-920.

13. Петриченко М.Р., Петроченко М.В., Явтушенко Е.Б. Гидравлически оптимальная вентилируемая щель // Инженерно-строительный журнал. 2013. № 2(37). C. 35-40.

14. Кнатько М.В., Ефименко М.Н., Горшков А.С. К вопросу о долговечности и энергоэффективности современных ограждающих стеновых конструкций жилых, административных и производственных зданий // Инженерно-строительный журнал. 2008. № 2. Рр. 5053.

15. Olshevskyi V., Statsenko E., Musorina T., Nemova D., Ostrovaia A. Moisture transfer in ventilated facade structures // MATEC Web of Conferences. 2016. Vol. 53. Pp. 1-5.

16. Korniyenko S. Evaluation of thermal performance of residential building envelope // Procedia Engineering. 2015. Vol. 117. Pp. 191-196.

17. Горшков А.С., Рымкевич П.П., Ватин Н.И. Моделирование процессов нестационарного переноса тепла в стеновых конструкциях из газобетонных блоков // Инженерно-строительный журнал. 2014. № 8. Рр. 3848

18. Rosca A.V., Pop I. Flow and heat transfer over a vertical permeable stretching/shrinking sheet with a second order slip // International Journal of Heat and Mass Transfer. 2013. № 60. Pp. 355-364.

19. Ватин Н.И., Немова Д.В. Повышение энергоэффективности зданий детских садов // Строительство уникальных зданий и сооружений. 2012. № 3. C. $52-76$.

20. Musorina T., Olshevskyi V., Ostrovaia A., Statsenko E. Experimental assessment of moisture transfer in the vertical ventilated channel // MATEC Web of Conferences. TPACEE 2016. 2016. Vol. 73. No. 02002.

Елена Александровна Стаценко, +7(981)8398538; staclena@mail.ru

Анастасия Федоровна Островая, +7(953)3449063; stasya2609@yandex.ru

Татьяна Александровна Мусорина, +7(952)2860376; flamingo-93@mail.ru

Максим Игоревич Куколев, +7(921)7540087; m_kukolev@mail.ru

Михаил Романович Петриченко, +7(921)3300429; fonpetrich@mail.ru

(c) Statcenko E.A., Ostrovaia A.F., Musorina T.A., Kukolev M.I., Petritchenko M.R., 2016

Стаценко Е.А., Островая А.Ф., Мусорина Т.А., Куколев М.И., Петриченко М.Р. Простая модель теплоустойчивой ограждающей конструкции // Инженерно-строительный журнал. 2016. № 8(68). С. 86-91. 